\title{
PENGARUH MEDIA TANAM DAN KONSENTRASI PUPUK ORGANIK CAIR TERHADAP PERTUMBUHANBIBIT KAKAO (Theobroma cacao L.)
}

\section{Effect of Growing Media and Concentration of Liquid Organic Fertilizer on the Growth of Cocoa Seeds (Theobroma cacao L.)}

\author{
Lismawati $^{1}$, Nurhayati ${ }^{1}$, Hasanuddin ${ }^{1}$ \\ ${ }^{1}$ Program Studi Agroteknologi PSDKU Gayo Lues, Fakultas Pertanian, Univeristas Syiah Kuala \\ lismawati04557@gmail.com
}

\begin{abstract}
Abstrak.Kakao merupakan salah satu komoditi hasil perkebunan yang mempunyai peranan penting dalam perekonomian Indonesia. Oleh karena itu perlu dilakukan upaya untuk meningkatkan mutu bibit kakao dengan cara perbaikan media tanam dan pemberian konsentrasi pupuk organik cair. Penelitian ini bertujuan untuk mengetahui pengaruh media tanam dan konsentrasi pupuk organik cair NAP yang tepat terhadap pertumbuhan bibit kakao serta untuk mengetahui interaksi antara kedua faktor tersebut.Penelitian ini menggunakan rancangan acak kelompok pola faktorial $5 \times 4$ dengan 3 ulangan. Faktor pertama adalah media tanam yang terdiri dari 5 taraf yaitu kontrol, tanah : pupuk kandang : cocopeat (2:1:1), tanah : pupuk kandang : cocopeat (1:1:1), tanah : pupuk kandang : cocopeat (1:2:1) dan tanah : pupuk kandang : cocopeat (1:1:2). Sedangkan faktor kedua adalah konsentrasi pupuk organik cair NAP yang terdiri dari 4 taraf yaitu kontrol, 5, 10 dan $15 \mathrm{ml} / \mathrm{L}$ air.Parameter yang diamati adalah tinggi tanaman, jumlah daun, diameter pangkal batang, panjang akar tunggang, volume akar, berat basah biomassa dan berat kering biomassa. Hasil penelitian menunjukan bahwa terdapat interaksi antara media tanam dan konsentrasi pupuk organik cair NAP yang berpengaruh sangat nyata terhadap diameter pangkal batang, volume akar, berat basah biomassa dan berat kering biomassa umur 90 HST serta berpengaruh nyata terhadap tinggi bibit umur 90 HST. Kombinasi perlakuan terbaik dijumpai pada perlakuan media tanam tanah : pupuk kandang : cocopeat (1:1:2) dengan konsentrasi pupuk organik cair NAP $10 \mathrm{ml} / \mathrm{L}$ air.
\end{abstract}

Kata Kunci : Bibit Kakao, Media Tanam, Pupuk Organik Cair

\begin{abstract}
Cocoa is one of the plantation commodities that has an imfortant role in the Indonesian economy. Therefore it is necessary to make efforts to improve the quality of cocoa seeds by improving the planting media and giving concentration of liquid organic fertilizer. This study aims to determine the effect of planting media and the appropriate concentration of liquid organic fertilizer NAP on the growth of cocoa seedlings and to determine the interaction between these two factors. This study used $5 \times 4$ factorial randomized block design with 3 replications. The first factor is the planting medium which consists of 5 levels namely control, soil : manure : cocopeat $(2: 1: 1)$, soil : manure : cocopeat $(1: 1: 1)$, soil : manure : cocopeat $(1: 2: 1)$ and soil : manure : cocopeat $(1: 1: 2)$. Meanwhile the secound factor is the concentration of liquid organic fertilizer NAP which consists of 4 levels namely control, 5, 10and $15 \mathrm{ml} / \mathrm{L}$ water. Parameters observed were plant height, number of leaves, stem diameter, taproot length, root volume, wet weight of biomass and dry weight of biomass. The results showed that there was an interaction between the planting medium and the concentration of liquid organic fertilizer NAP which had a very significant effect on stem diameter, root volume, biomass wet weight, and dry weight of biomass at 90 DAP and had a significant affected seedling height at 90 DAP. The best combination treatments was found in the treatmentof soil planting media : manure : cocopeat (1:1:2) with a concentration of liquid organic fertilizer NAP $10 \mathrm{ml} / \mathrm{L}$ water.
\end{abstract}

Keywords : Cocoa Seeds, Planting Media, Liquid Organic Fertilizer

\section{PENDAHULUAN}

Kakao adalah suatu komoditas hasil perkebunan yang memilki peran penting dalam kegiatan perekonomian di Indonesia, kakao juga merupakan suatu komoditi andalan Indonesia sebagai penghasil devisa negara selain minyak dan gas. Indonesia adalah negara produsen dan eksportir kakao terbesar ketiga dunia setelah Ghana dan Pantai Gading(Badan Pusat Statistik, 
2018). Produksi tanaman kakao di Indonesia mulai tahun 2016 adalah sebanyak 658.399 ton, tahun 2017 sebanyak 590.684 ton, tahun 2018 sebanyak 767.280 ton, tahun 2019 sebanyak 783.978 ton dan pada tahun 2020 sebanyak 733.483 ton (Direktorat Jendral Perkebunan, 2020). Dari data tersebut dapat dilihat bahwa terjadinya ketidaknormalan produksi kakao setiap tahunnya.

Salah satu penyebab ketidaknormalan hasil kakao yaitu tidak adanya ketersediaan bibit bermutu sehingga perlu dilakukan usaha untuk meningkatkan kualitas bibit kakao dengan memperbaiki sistem agronominya melalui perbaikan media tanam dan konsentrasi pupuk organik cair.Strategi pengembangan adalah suatu faktor yang memberikan keuntungan dalam meningkatkan mutu bibit kakao. Benih yang berkualitas tinggi akan memberikan peluang besar untuk mencapai hasil yang optimal (Armaini et al., 2017). Upaya untuk mendapatkan bibit yang bermutu adalah dengan memperhatikan media tanam. Penggunaan tanah sebagai media tanam tidak cukup untuk memenuhi kebutuhan nutrisi yang diperlukan oleh tanaman, sehingga perlu dilakukan penambahan bahan organik seperti pupuk kandang, dan sabut kelapa/cocopeat. Setiap bahan organik memiliki keunggulan sehingga cenderung dimanfaatkan untuk meningkatkan kualitas bibit tanaman kakao.Media tanam pada prinsipnya harus mampu meberikan nutrisi, oksigen dan air bagi tanaman. Pemamfaatan bahan tanam yang yang sesuai akan memberikan perkembangan yang ideal bagi bibit kakao (Zaenuddin, 2012).

Media tanam erat kaitannya dengan perkembangan tanaman, penggunaan sistem media tanam yang baik akan mempengaruhi siklus pengambilan hara dan akar tanaman sehingga perkembangan tanaman dapat berjalan ideal. Hasil penelitian Mulyani et al., (2018) menyatakan bahwa media tanam bepengaruh nyata terhadap parameter tinggi dan panjang akar bibit kako umur 60 HST.Selain memperhatikan media tanam pemberian pupuk organik cair juga sangat diperlukan untuk melengkapi kebutuhan hara bibit tanaman kakao.Pupuk organik cair ramah lingkungan mengandung bahan penting yang dapat menyuburkan tanah baik secara fisik, kimia ataupun biologi tanah.Pupuk alami dapat berfunggsi sebagai pemantap agregat tanah dan tanaman. Pupuk organik cair merupakan larutan daril pembusukan bahan alam yang berasal dari kotoran manusia, tanaman dan kotoran hewan, (Kardi, 2016).

Salah satu pupuk organik cair yang beredar dipasaran yaitu pupuk organik cair NAP (Nutri Agro Plus), Kandungan unsur hara yang terdapat dalam POC NAP adalah $25 \%$ C.organik, $0.05 \%$ P, 0,01 \% K, 12,89 ppm Fe, 1,05 ppm Mn, 1,07 ppm Cu, 1,0 ppm Zn, 4,0 ppm B, 16,1 ppm Mo dan $\mathrm{pH}>4$. POC NAP juga mengandung zat pengatur tumbuh yaitu giberelin, auksin, dan sitokinin. Konsentrasi anjuran POC NAP adalah 10-30 ml/L air dan diberikan dengan cara disemprot kesekitar perakaran tanaman (PT. Suba Indah).

\section{METODE PENELITIAN}

\section{Tempat dan Waktu}

Penelitian ini dilakukan di Kebun Percobaan Sektor Timur dan Labortorium Ilmu dan Teknologi Benih Fakultas Pertanian Universitas Syiah Kuala, Darussalam Banda Aceh dilaksanakan dari November 2020 hingga Februari 2021. 


\section{Alat dan bahan}

Alat-alat yang digunakan dalam penelitian ini adalah cangkul, ayakan tanah, goni, gembor, meteran, gelas ukur, jangka sorong, timbangan analitik, amplop, lebel, oven, kamera dan alat tulis. Bahan-bahan yang digunakan adalah bibit kakao varietas Celebes, tanah (top soil) berasal dari Ulee Kareng, pupuk kandang sapi, cocopeat, pupuk organik cair NAP, fungisida Dithane M-45, polibag ukuran $25 \mathrm{~cm}$ x $25 \mathrm{~cm}$ dan naungan (paranet).

\section{Rancangan Percobaan}

Penelitian ini menggunakan Rancangan Acak Kelompok (RAK) pola faktorial 5x4 dengan 3 kali ulangan sehingga terdapat 60 satuan percobaan, Ada dua faktor yang diteliti. Faktor pertama adalah media tanam yang terdiri atas lima taraf $\mathrm{M}_{0}=$ Tanah (Kontrol), $\mathbf{M}_{1}=$ Tanah : Pupuk Kandang : Cocopeat $(2: 1: 1), \mathbf{M}_{2}=$ Tanah $:$ Pupuk Kandang : Cocopeat (1:1:1), $\mathbf{M}_{3}=$ Tanah : Pupuk Kandang : Cocopeat (1:2:1), $\mathbf{M}_{4}=$ Tanah : Pupuk Kandang : Cocopeat (1:1:2). Faktor kedua adalah konsentrasi pupuk organik cair (POC NAP) yang terdiri atas empat taraf $\mathrm{P}_{0}=$ Kontrol, $\mathrm{P}_{1}=5 \mathrm{ml} / \mathrm{L}$ air, $\mathrm{P}_{2}=10 \mathrm{ml} / \mathrm{L}$ air dan $\mathrm{P}_{3}=15 \mathrm{ml} / \mathrm{L}$ air.

\section{Pelaksanaan Penelitian \\ Pembuatan naungan}

Pembuatan naungan menggunakan paranet dengan tinggi sekitar 2 meter.Naungan yang digunakan adalah paranet $75 \%$ menahan cahaya matahari sehingga cahaya yang diterima bibit tanaman kakao adalah sebesar $25 \%$.

\section{Mempersiapkan Media Tanam}

Media yang digunakan yaitu tanah yang terlebih dahulu diayak untuk membersihkan sisa-sisa akar dan kotoran yang ada pada tanah, pupuk kandang juga dikering anginkan.Media tanam dicampur sesuai dengan perlakuan berdasarkan volume.Setelah semua bahan tercampur sesuai dengan perlakuan kemudian media tanam didiamkan selama 1 minggu agar semua bahan yang digunakan dapat terdekomposisi dengan sempurna.Setelah satu minggu media tanam dimasukan ke dalam polibag.

\section{Persiapan Benih Kakao}

Benih kakao yang dipakai yaitu varietas Celebes, Benih kakao yang digunakan adalah benih dari buah yang terletak pada batang utama kakao.Benih yang digunakan adalah benih baik dan sudah mencapai masak fisiologis dengan kriteria buah berwarna kekuningan.

\section{Perkecambahan benih}

Benih kakao terlebih dahulu dibersihkan dari pulp dengan cara mengosok benih menggunakan abu sekam padi. Benih yang telah bebas dari pulp dicuci terlebih dahulu kemudian direndam selama 5 menit dalam larutan fungisida Dithante M-45 dengan konsentrasi 0,2\%, kemudian diletakan diatas goni basah sampai benih berkecambah yaitu selama 7 hari.

\section{Pemindahan Kecambah}

Pemindahan kecambah dilakukan secara serentak yaitu pada sore hari.Dimana setiap polibag diletakan satu kecambah.Sebelum kecambah dipindahkan terlebih dahulu media 
tanam disiram dengan air sampai mencapai kapasitas lapang untuk menciptakan lingkungan yang baik bagi pertumbuhan tanaman.

\section{Pemupukan}

Pemberian pupuk organik cair NAP dilakukan pada umur 15, 30 dan 45 hari setelah tanam.Konsentrasi pupuk yang digunakan adalah 0, 5, 10 dan $15 \mathrm{ml} / \mathrm{L}$ air. Pemberian pupuk yang telah dilarutkan dengan air diberikan dengan cara disiram ke sekitar perakaran tanaman, sebanyak $150 \mathrm{ml} /$ polibag.

\section{Pemeliharaan}

Penyiraman

Penyiraman dilakukan dengan menggunakan gembor, yaitu pada sore hari atau disesuaikan dengan keadaan bibit kakao di lapangan.

\section{Penyiangan}

Penyiangan dilakukan 1 minggu sekali yaitu dengan cara manual, selain dilakukan pembersihan gulma pengemburan tanah juga dilakukan pada saat penyiangan.

\section{Pengamatan}

Parameter yang diamati dalam penelitian ini adalah tinggi tanaman $(\mathrm{cm})$, jumlah daun (helai), diameter pangkal batang $(\mathrm{mm})$, panjang akar tunggang $(\mathrm{cm})$, volume akar $(\mathrm{ml})$, berat basah biomassa (g) dan berat kering biomassa $(\mathrm{g})$.

\section{HASIL DAN PEMBAHASAN}

\section{Pengaruh Media Tanam terhadap Pertumbuhan Bibit Kakao}

Tabel 1.Rata-rata parameter pertumbuhan bibit kakao akibat perlakuan media tanam

\begin{tabular}{|c|c|c|c|c|c|c|c|}
\hline & & Medi & Tanam $\mathrm{T}$ & lah : P. Ka & dang : Co & peat & \\
\hline Paramet & & $\mathrm{M}_{0}$ & $\mathrm{M}_{1}$ & $\mathrm{M}_{2}$ & $\mathrm{M}_{3}$ & $\mathrm{M}_{4}$ & $\mathrm{BNJ}$ \\
\hline Tinggi Bibit & $30 \mathrm{HST}$ & $18,75 \mathrm{a}$ & $20,04 \mathrm{ab}$ & $19,06 \mathrm{ab}$ & $19,00 \mathrm{ab}$ & $20,58 \mathrm{~b}$ & 1,59 \\
\hline Kakao $(\mathrm{cm})$ & $60 \mathrm{HST}$ & $21,08 \mathrm{a}$ & $22,69 \mathrm{ab}$ & $21,25 \mathrm{ab}$ & $21,13 \mathrm{a}$ & $22,83 \mathrm{~b}$ & 1,68 \\
\hline & 90 HST & $23,82 \mathrm{a}$ & $28,89 \mathrm{~b}$ & $27,23 \mathrm{~b}$ & $27,25 \mathrm{~b}$ & $29,03 \mathrm{~b}$ & 1,87 \\
\hline Jumlah Daun & 30 HST & $3,83 \mathrm{a}$ & $4,00 \mathrm{ab}$ & $4,17 \mathrm{ab}$ & $4,04 \mathrm{ab}$ & $4,42 \mathrm{~b}$ & 0,48 \\
\hline (Helai) & 60 HST & $6,79 \mathrm{a}$ & $8,38 \mathrm{bc}$ & $8,04 \mathrm{~b}$ & $8,13 \mathrm{~b}$ & $8,96 \mathrm{c}$ & 0,79 \\
\hline & 90 HST & $9,42 \mathrm{a}$ & $12,21 \mathrm{~b}$ & $12,04 \mathrm{~b}$ & $12,17 \mathrm{~b}$ & $14,08 \mathrm{c}$ & 1,17 \\
\hline Diameter & $30 \mathrm{HST}$ & $3,28 \mathrm{a}$ & $3,50 \mathrm{ab}$ & $3,54 \mathrm{ab}$ & $3,48 \mathrm{ab}$ & $3,60 \mathrm{~b}$ & 0,28 \\
\hline Pangkal & $60 \mathrm{HST}$ & $4,50 \mathrm{a}$ & $5,40 \mathrm{~b}$ & $5,18 \mathrm{~b}$ & $5,21 \mathrm{~b}$ & $5,60 \mathrm{~b}$ & 0,46 \\
\hline Batang (mm) & 90 HST & $5,35 \mathrm{a}$ & $6,88 \mathrm{~b}$ & $6,58 \mathrm{~b}$ & $6,70 \mathrm{~b}$ & $8,23 \mathrm{c}$ & 0,55 \\
\hline $\begin{array}{l}\text { Panjang Akar } \\
\text { Tunggang }(\mathrm{cm})\end{array}$ & & $12,13 \mathrm{a}$ & $15,35 \mathrm{ab}$ & $14,40 \mathrm{ab}$ & $16,65 b$ & $15,41 \mathrm{ab}$ & 3,90 \\
\hline
\end{tabular}




\begin{tabular}{lcccccc}
\hline Volume Akar (ml) & $2,60 \mathrm{a}$ & $3,44 \mathrm{~b}$ & $3,32 \mathrm{~b}$ & $3,32 \mathrm{~b}$ & $4,59 \mathrm{c}$ & 0,57 \\
& & & & & & \\
\hline $\begin{array}{l}\text { Berat Basah Biomassa } \\
\text { (g) }\end{array}$ & $9,18 \mathrm{a}$ & $16,52 \mathrm{c}$ & $13,63 \mathrm{~b}$ & $14,85 \mathrm{bc}$ & $18,79 \mathrm{~d}$ & 1,90 \\
& & & & & &
\end{tabular}

\begin{tabular}{lllllll}
\hline $\begin{array}{l}\text { Berat Kering Biomassa } \\
(\mathrm{g})\end{array}$ & $3,01 \mathrm{a}$ & $5,15 \mathrm{c}$ & $3,33 \mathrm{~b}$ & $4,71 \mathrm{bc}$ & $5,79 \mathrm{~d}$ & 0,59 \\
\hline
\end{tabular}

Keterangan : Angka-angka yang diikuti huruf yang sama pada baris yang sama tidak berbeda nyata pada taraf $0.05 \%\left(\mathrm{uji} \mathrm{BNJ}_{0.05}\right)$

Tabel 1 memperlihatkan bahwa pertumbuhan bibit kakao terbaik dijumpai pada perlakuan media tanam tanah : pupuk kandang : cocopeat $(1: 1: 2)$ yang secara umum ditandai dengan pertumbuhan tinggi bibit yang baik, jumlah daun yang banyak, diameter batang yang besar, volume akar yang besar, berat basah dan berat kering berangkasan yang baik. Hal ini diduga karena penambahan bahan organik seperti pupuk kandang dan cocopeat mampu memberikan lingkungan yang baik dan sesuai bagi pertumbuhan dan perkembangan bibit kakao, cocopeat juga mampu memberikan aerase dan darinase yang baik sehingga dapat memudahkan akar untuk menyerap unsur hara secara intensif dan dapat mempercepat laju pertumbuhan bibit kakao.Hal ini Sesuai dengan pendapat (Mulyani et al., 2018) yang menyatakan bahwa media tanam tanah, pupuk kandang dan cocopeat mampu menciptakan lingkungan yang baik bagi pertumbuhan dan perakaran tanaman, sehingga dapat menyebabkan proses absorbsi berjalan dengan seimbang. Ketersediaan unsur hara bagi tanaman akan meningkatkan proses fotosintesis pada tanaman, dengan demikian fotosintat yang dihasilkan melalui proses fotosintesis diangkut keseluruh bagian tanaman untuk pertumbuhan organ-organ tanaman dan apabila jumlah fotosintat yang dihasilkan mencukupi maka pertambahan tinggi tanaman, diameter batang, jumlah daun, nisbah tajuk akar, berat basah berangkasan serta berat kering berangkasan akan menjadi lebih baik (Ridawati, 2013).

\section{Pengaruh Konsentrasi Pupuk Organik Cair NAP terhadap Pertumbuhan Bibit Kakao}

Tabel 2. Rata-rata parameter pertumbuhan bibit kakao akibat perlakuan konsentrasi pupuk organik cair NAP

Konsentrasi Pupuk Organik Cair NAP (ml/L air)

\begin{tabular}{cccccc}
\cline { 2 - 4 } & $\begin{array}{c}\mathrm{P}_{0} \\
\text { Paramtrol })\end{array}$ & $\mathrm{P}_{1}(5)$ & $\mathrm{P}_{2}(10)$ & $\mathrm{P}_{3}(15)$ & $\begin{array}{c}\text { BNJ } \\
(0,05)\end{array}$
\end{tabular}

\begin{tabular}{lcccccc}
\hline Tinggi Bibit & 30 HST & 18,95 & 19,50 & 19,87 & 19,63 & - \\
Kakao $(\mathrm{cm})$ & 60 HST & 21,05 & 21,97 & 22,12 & 22,05 & - \\
& $90 \mathrm{HST}$ & $25,81 \mathrm{a}$ & $27,34 \mathrm{ab}$ & $28,28 \mathrm{~b}$ & $27,54 \mathrm{~b}$ & 1,57 \\
& & & & & & \\
\hline Jumlah Daun & $30 \mathrm{HST}$ & 4,00 & 4,13 & 4,07 & 4,17 & - \\
(Helai) & $60 \mathrm{HST}$ & 8,00 & 7,97 & 8,23 & 8,03 & - \\
& $90 \mathrm{HST}$ & $11,33 \mathrm{a}$ & $12,10 \mathrm{ab}$ & $12,33 \mathrm{~b}$ & $12,17 \mathrm{ab}$ & 0,98 \\
& & & & & & \\
\hline Diameter & $30 \mathrm{HST}$ & 3,39 & 3,45 & 3,59 & 3,47 & - \\
Pangkal & $60 \mathrm{HST}$ & 5,17 & 5,13 & 5,22 & 5,20 & - \\
Batang (mm) & $90 \mathrm{HST}$ & $6,55 \mathrm{a}$ & $6,79 \mathrm{ab}$ & $7,11 \mathrm{~b}$ & $6,55 \mathrm{a}$ & 0,46 \\
& & & & & & \\
\hline
\end{tabular}




\begin{tabular}{llllll}
\hline Panjang Akar & 12,81 & 14,98 & 15,90 & 15,46 & - \\
Tunggang $(\mathrm{cm})$ & & & & &
\end{tabular}

\begin{tabular}{lccccc}
\hline Volume Akar (ml) & $2,94 \mathrm{a}$ & $3,58 \mathrm{~b}$ & $3,73 \mathrm{~b}$ & $3,56 \mathrm{~b}$ & 0,48 \\
\hline Berat Basah Biomassa (g) & $12,41 \mathrm{a}$ & $13,87 \mathrm{a}$ & $16,25 \mathrm{~b}$ & $15,84 \mathrm{~b}$ & 1,59 \\
& & & & & \\
\hline
\end{tabular}

Tabel 2 memperlihatkan bahwa pertumbuhan bibit kakao terbaik akibat perlakuan konsentrasi pupuk organik cair NAP dijumpai pada perlakuan $10 \mathrm{ml} / \mathrm{L}$ air. Hal ini diduga karena unsur hara yang terkandung dalam pupuk organik cair NAP $10 \mathrm{ml} / \mathrm{L}$ air sudah mampu melengkapi kebutuhan unsur hara yang diperlukan bibit kakao selama masa pertumbuhan dan perkembangannya, dimana dengan konsentrasi tersebut unsur hara berada dalam keadaan yang seimbang sehingga baik untuk pertumbuhan bibit kakao. Sesuai dengan pendapat Gunawan et al., (2015) yang menyatakan bahwa pemberian bahan organik berupa pupuk organik cair selain dapat menyediakan unsur hara yang diperlukan oleh tanaman, pupuk organik juga bisa memperbaiki sifat fisik tanah.Dwijoseputro (1996) menyatakan bahwa suatu tanaman akan tumbuh subur apabila semua unsur hara tersedia dalam jumlah yang cukup dan dalam bentuk yang sesuai untuk dapat diserap oleh tanaman selama masa pertumbuhannya

\section{Pengaruh Interaksi Antara Media Tanam dan Konsentrasi Pupuk Organik Cair NAPterhadap Pertumbuhan Bibit Kakao}

Tabel 3. Interaksi antara media tanam dan konsentrasi pupuk organik cair NAP terhadap pertumbuhan bibi kako

\begin{tabular}{|c|c|c|c|c|c|c|}
\hline \multirow{2}{*}{$\begin{array}{c}\text { Parameter } \\
\text { Yang diamati }\end{array}$} & \multirow{2}{*}{$\begin{array}{c}\text { Jenis media } \\
\text { tanam }\end{array}$} & \multicolumn{4}{|c|}{ Konsentrasi POC NAP (ml/L air) } & \multirow{2}{*}{$\begin{array}{l}\text { BNJ } \\
(0,05)\end{array}$} \\
\hline & & $\mathrm{P}_{0}$ (Kontrol) & $\mathrm{P}_{1}(5)$ & $\mathrm{P}_{2}(10)$ & $\mathrm{P}_{3}(15)$ & \\
\hline Tinggi Bibit & $\mathrm{M}_{0}$ & $20,58 \mathrm{Aa}$ & $23,75 \mathrm{ABa}$ & $25,25 \mathrm{Aba}$ & $25,68 \mathrm{Ba}$ & \multirow{5}{*}{4,96} \\
\hline \multirow[t]{4}{*}{ Kakao $90(\mathrm{~cm})$} & $\mathrm{M}_{1}$ & $29,50 \mathrm{Ab}$ & 27,92 Aab & $29,55 \mathrm{Aab}$ & $28,58 \mathrm{Aa}$ & \\
\hline & $\mathrm{M}_{2}$ & $26,83 \mathrm{Ab}$ & 26, $75 \mathrm{Aab}$ & 27,77 Aab & $27,55 \mathrm{Aa}$ & \\
\hline & $\mathrm{M}_{3}$ & $26,97 \mathrm{Ab}$ & 27,30 Aab & $28,20 \mathrm{Aab}$ & $26,55 \mathrm{Aa}$ & \\
\hline & $\mathrm{M}_{4}$ & 25, 17 Aab & $31,00 \mathrm{Bb}$ & $30,63 \mathrm{Bb}$ & $29,33 \mathrm{ABa}$ & \\
\hline Diameter & $\mathrm{M}_{0}$ & $4,90 \mathrm{Aa}$ & $5,35 \mathrm{Aa}$ & $5,58 \mathrm{Aa}$ & $5,58 \mathrm{Aa}$ & \multirow{5}{*}{1,46} \\
\hline Pangkal & $\mathrm{M}_{1}$ & $6,95 \mathrm{Ab}$ & 7,23 Abc & 6,98 Aa & 6,37 Aab & \\
\hline Batang & $\mathbf{M}_{2}$ & $6,57 \mathrm{Ab}$ & 6,23 Aab & 6,75 Aa & 6,77 Aab & \\
\hline \multirow[t]{2}{*}{$90 \mathrm{HST}(\mathrm{mm})$} & $\mathrm{M}_{3}$ & $6,78 \mathrm{Ab}$ & $6,65 \mathrm{Aab}$ & 6,63 Aa & 6,75 Aab & \\
\hline & $\mathrm{M}_{4}$ & $7,55 \mathrm{Ab}$ & $8.48 \mathrm{ABc}$ & $9,60 \mathrm{Bb}$ & $7,27 \mathrm{Ab}$ & \\
\hline
\end{tabular}




\begin{tabular}{lllllll}
\hline $\begin{array}{l}\text { Volume Akar } \\
(\mathrm{g})\end{array}$ & $\mathrm{M}_{0}$ & $2,27 \mathrm{Aa}$ & $2,98 \mathrm{Aa}$ & $2,33 \mathrm{Aa}$ & $2,82 \mathrm{Aa}$ & \\
& $\mathrm{M}_{1}$ & $3,25 \mathrm{Aa}$ & $3,92 \mathrm{Aab}$ & $3,42 \mathrm{Aa}$ & $3,17 \mathrm{Aab}$ & \\
& $\mathrm{M}_{2}$ & $3,08 \mathrm{Aa}$ & $2,87 \mathrm{Aa}$ & $3,67 \mathrm{Aa}$ & $3,67 \mathrm{Aab}$ & 1,53 \\
& $\mathrm{M}_{3}$ & $2,85 \mathrm{Aa}$ & $3,33 \mathrm{Aab}$ & $3.58 \mathrm{Aa}$ & $3,50 \mathrm{Aab}$ & \\
& $\mathrm{M}_{4}$ & $3,25 \mathrm{Aa}$ & $4,82 \mathrm{Bb}$ & $5,63 \mathrm{Bb}$ & $4,65 \mathrm{ABb}$ & \\
& & & & & & \\
\hline Berat Basah & $\mathrm{M}_{0}$ & $7,25 \mathrm{Aa}$ & $8,92 \mathrm{Aa}$ & $10,47 \mathrm{Aa}$ & $10,09 \mathrm{Aa}$ & \\
Bimassa (g) & $\mathrm{M}_{1}$ & $13,60 \mathrm{Ab}$ & $16,35 \mathrm{Ab}$ & $18,56 \mathrm{Abc}$ & $17,59 \mathrm{Abc}$ & \\
& $\mathrm{M}_{2}$ & $12,92 \mathrm{Ab}$ & $13,24 \mathrm{Aab}$ & $13,54 \mathrm{Aab}$ & $14,81 \mathrm{Aab}$ & 5,05 \\
& $\mathrm{M}_{3}$ & $14,41 \mathrm{Ab}$ & $13,99 \mathrm{Aab}$ & $15,52 \mathrm{Aab}$ & $15,46 \mathrm{Ab}$ & \\
& $\mathrm{M}_{4}$ & $13,89 \mathrm{Ab}$ & $16,84 \mathrm{ABb}$ & $23,15 \mathrm{Cc}$ & $21,28 \mathrm{BCc}$ & \\
& & & & & & \\
& $\mathrm{M}_{0}$ & $2,65 \mathrm{Aa}$ & $3,06 \mathrm{Aa}$ & $3,10 \mathrm{Aa}$ & $3,25 \mathrm{Aa}$ & \\
& $\mathrm{M}_{1}$ & $4,81 \mathrm{Ab}$ & $4,99 \mathrm{Ab}$ & $5,52 \mathrm{Ab}$ & $5,28 \mathrm{Ab}$ & \\
Berat Kering & $\mathrm{M}_{2}$ & $4,08 \mathrm{Aab}$ & $4,29 \mathrm{Aab}$ & $4,20 \mathrm{Aab}$ & $4,75 \mathrm{Aab}$ & 1,57 \\
& $\mathrm{M}_{3}$ & $4,83 \mathrm{Ab}$ & $4,79 \mathrm{Ab}$ & $4,46 \mathrm{Aab}$ & $4,77 \mathrm{Aab}$ & \\
& $\mathrm{M}_{4}$ & $4,49 \mathrm{Ab}$ & $5,21 \mathrm{ABb}$ & $7,14 \mathrm{Cc}$ & $6,31 \mathrm{BCb}$ & \\
& & & & & &
\end{tabular}

Keterangan: Angka-angka yang diikuti huruf yang sama sama (huruf kapital dilihat secara horizontal dan huruf kecil dilihat secara vertikal) tidak berbeda nyata pada taraf $0,05 \%$ (uji $\mathrm{BNJ}_{0,05}$ )

Tabel 3 memperlihatkan bahwa kombinasi perlakuan terbaik dijumpai pada media tanam tanah : pupuk kandang : cocopeat (1:1:2) dengan konsentrasi pupuk organik cair NAP $10 \mathrm{ml} / \mathrm{L}$ air. Hal ini diduga karena media tanam tanah, pupuk kandang dan cocopeat mampu memperbaiki struktur tanah menjadi lebih baik dan konsentrasi $10 \mathrm{ml} / \mathrm{L}$ air dapat melengkapi ketersediaan unsur hara sehingga bibit kakao dapat tumbuh dengan optimal. Dengan adanya cocopeat dalam penelitian ini maka media tanam mampu mengikat dan menyimpan air serta mengandung unsur-unsur hara esensial seperti kalium (K), Fosfor (P), Kalsium (Ca), Natrium (N) dan Magnesium (Mg) (Muliawan, 2009). Salah satu manfaat unsur Fosfor adalah mempercepat serta memperkuat tumbuhan muda, unsur $\mathrm{Ca}$ berfungsi sebagai pembuatan protein dan $\mathrm{Mg}$ berfungsi sebagai trasformasi Fosfor pada bagian tanaman yang aktif dan dapat memacu pembesaran pada bagian batang tanaman (Lingga dan Marsono, 2010).

Menurut Munawar, (2003) pemberian pupuk organik cair ke dalam tanah akan memberikan nutrisi yang dibutuhkan tanaman dalam jangka panjang serta makanan bagi mikroorganisme di dalam tanah sehingga dapat mendorong laju perkembangan tanaman. Selanjutnya menurut Rikamonika, (2012) menyatakan bahwa fungsi pupuk organik cair adalah memberikan unsur hara pada tanaman yang lengkap yaitu unsur hara makro dan mikro yang dapat meningkatkan pertumbuhan tanaman.Unsur hara yang terkandung dalam pupuk kandang serta cocopeat diduga mampu meningkatkan perkembangan menjadi lebih cepat selain itu kandungan $\mathrm{C}$ organik dan hara lain yang terdapat dalam pupuk organik cair dapat melengkapi keperluan bibit kakao akan unsur hara sehingga saat media tanam tanah, pupuk kandang serta cocopeat dikombinasikan dengan pupuk organik cair NAP maka akan terjadi interaksi antara kedua faktor tersebut.

\section{KESIMPULAN DAN SARAN}

\section{Kesimpulan}

Perlakuan media tanam terbaik terhadap pertumbuhan bibit kakao dijumpai pada media tanam tanah, pupuk kandang dan cocopeat (1:1:2). Perlakuan pupuk organik cair 
NAPterhadap pertumbuhan bibit kakaoyang sesuai dijumpai pada konsentrasi $10 \mathrm{ml} / \mathrm{L}$ air.Pertumbuhan bibit kakao terbaik dijumpai pada kombinasi media tanam tanah, pupuk kandang dan cocopeat (1:1:2)dengan konsentrasi pupuk organik cair NAP $10 \mathrm{ml} / \mathrm{L}$ air.

\section{DAFTAR PUSTAKA}

Armaini.,S. Yoseva., dan A. Hasiholan. 2017. Pengaruh perbedaan limbah cair bioetanol (Vinasse) terfermentasi terhadap pertumbuhan bibit tanaman kakao (Theobroma cacao L.). Jurnal Faperta. 4(2):1-15.

Badan Pusat Statistik. 2018. Data Produksi Tanaman Kakao Indonesia. Badan Pusat Statistik. Jakarta.

Direktorat Jendral Perkebunan. 2020. Produktivitas Tanaman Kakao di Indonesia Tahun 2016-2020. http://jakarta.litbang.pertanian.go.id/phocadowload/kakao.pdf.

Dwijoseputro, D. 1996. Pengantar Fisiologi Tumbuhan. PT Gramedia, Jakarta.

Gunawan, T., S, I, Saputra., dan K, R, Ginting. 2015. Pertumbuhan bibit kakao (Theobromacacao L.) yang ditanam pada beberapa medium tumbuh dengan pemberian pupuk organik cair. Jurnal Online Mahasiswa Fakultas Pertanian Riau. 2(1)1-10.

Kardi, Y. 2016. Pemberian pupuk organik cair terhadap pertumbuhan bibit kelapa sawit (Elais quinensis Jacq.) pada pembibitan utama. Jurnal Faperta. 3(2)1-12.

Lingga, P dan Marsono. 2010. Petunjuk Penggunaan Pupuk. Penebar Swadaya. Jakarta

Mulyani, C.,I.Saputra., danR. Kurniawan. 2018. Pengaruh media tanam dan limbah organik terhadap pertumbuhan kakao (Theobroma cacao L.). Jurnal Agrosamudra. 5(2):1-14.

Munawar, E.I. 2003. Pupuk Organik. Penebar Swadaya, Jakarta.

Ridawati, M. 2013. Pertumbuhan bibit kakao (Theobroma cacao L) dengan pemberian beberapa dosis pupuk NPK (16:16:16) pada tanah ultisol di polibag. Jurnal Ilmiah Universitas Batanghari Jambi 13(4):95-98.

Rikamonika, 2012.Respon tanaman kelapa sawit terhadap pupuk fospat alam berkualitas tinggi untuk mendorong peningkatan produksi tanaman perkebunan.Skripsi.Fakultas Pertanian Universitas Sumatra Utara. Medan.

Zaenuddin.2012. Klasifikasi Tanah Dasar Teori Berbagi Penelitian Tanah dan Pelaksanaan Pertanian di Indonesia.Gajah Mada University Press, Yogyakarta. 